\title{
Assessing the Need of Modern Education in Madrassah System: A Case Study of Madaris in Lahore
}

Ubair Anjum*

University of Punjab, Lahore, Pakistan

"Corresponding author: Anjum U, University of Punjab, Lahore, Pakistan, Tel: 0092-42-99233132; E-mail: mubairanjum@gmail.com

Received date: July 06, 2017; Accepted date: July 24, 2017; Published date: July 28, 2017

Copyright: (c) 2017 Anjum U. This is an open-access article distributed under the terms of the Creative Commons Attribution License, which permits unrestricted use, distribution, and reproduction in any medium, provided the original author and source are credited.

\begin{abstract}
This paper focuses on the needs of modification of curriculum and education system of the madaris in Lahore. As the changing situations of peace across the globe along with the advent of $9 / 11$, so madrassa educational system has gained much attention because of purported relationship between the madrassah students and terrorism. Appositeness between the educational prospects of madrassas and terrorism has become an igneous argument. In this manner, a quantitative research design is implemented for investigating the target result. The data was collected by the researcher himself while conducting face to face interviews with the 107 respondents. This interview based on open-ended questions. So the population of the present research comprised of 107 participants from the district Lahore. The data analyzed in descriptive statistic tables and by applying chi-square test. Hence, this study would be an incentive in illuminating a contrastive study on madrassah education and modern studies which can help the graduate students in dealing effectively with the challenges of modern world. In addition to this, some productive suggestions exist in the proceeding chapters too. SPSS used for the systematic evaluation of the data.
\end{abstract}

Keywords: Curriculum; Madaris; Questionnaire; SPSS

\section{Introduction}

The role education of education in the society cannot be repudiated. An entrenched educational framework is an essential constituent of a socialized country and society. Its significance is obvious in third world countries especially, as it plays a noteworthy role in the improvement of individual and social infrastructure of society. As an alternative educational system in comparison to the Western educational system, religious education from madaris has played a vital role in the history of Islam by fulfilling the needs of Islamic society. Despite fact that madaris are the most indigenous Islamic education institutions in Pakistan, they have always been at the focal point of discussion on radicalization and extremism of society since Pakistan joined the US war on terrorism after $9 / 11$.

\section{Fundamentalism and extremism}

Fundamentalism and extremism are the most recognized buzzwords highlighted across the globe during the war of terror. Not only this but these terminologies are ceaselessly attached with the madaris. There has no solution offered for the problem of extremism so far and this has become hefty scapegoats for the rest of world. The madaris are considered as a critical medium for promoting religious extremism, sectarian, social and political views which lead towards the terrorism. This is the most highlighted time and again there is a need to change conventional philosophies of madaris with legitimate Islamic values, and provides a productive and valuable curriculum to madaris, so that these madaris graduates become valuable and pragmatic individuals for society. Educational system of madrassa does not provide job opportunities equal to that of modern education system due to this madrassah graduates are involved in illegitimate activities after the completion of their education from the prospective madrassas.
Especially western world is completely in favor of doctrine that these educational institutions are generating capacious number of terrorists. Educational curriculums taught at madrassas are not according to the devoir of modern world.

In recent years number of articles published in different newspapers have brought up the facts about the increasing number of madrassas in Pakistan and other important facts related to the origination of sectarianism, politics and extremism from these institutions. According to the article published by Indo-Asian news, after independence of Pakistan, the number of madrassas has been increased gradually. At the time of independence, Pakistan had total number of madrassas between 137 and 245, which reaches to 401 till the year of 1960 . The number of madrassas in 2001 had reached to 6,870. And till 2013 the number has increased above 50,000. Almost 1.5 million students are attending these institutions [1].

\section{Status of madrassas in Pakistan}

Madaris in Pakistan are considered as non-governmental organizations that provide students with Islamic education along with the free boarding and lodging facilities, in order to educate the segment of society based on poor people. These institutions follows Islamic curriculum designed especially for this purpose. Along with the other educational system in country, religious education is also reckoned as the vital part of educational system. There are three parallel education systems in Pakistan government funded schools, private schools, furthermore, Islamic religious schools. Both private and public schools teaches Islamic subjects as a substantial part of their curriculum, while madaris offer absolutely religious training for the students who have keen interest of specializing in religious education. In these conditions, regardless of the possibility that madaris are opposed by a society, numerous among the masses keep on supporting them. 
Page 2 of 8

It can be stated clearly that the concepts about the characteristics and nature of the madrassah are deviated from their original over the certain period of time. At earlier times of Islam, madrassahs were the origin of Islamic education and knowledge. Not only this but other subjects related to modern sciences like astronomy, physics, mathematics, chemistry etc. have also their research roots in these madrassahs. However, with the downfall of the Islamic civilization these institutions also gradually lost their academic excellence. Muslims in the Indian subcontinent associated with the madrassa tradition, but with the advent of the modern colonial education system, these institutions are only restricted to the religious domain. These institutions did produce some eminent religious scholars in the subcontinent, such as Allama Shibli Naumani, Maulana Altaf Hussain Hali and Sayyid Suleman Nadvi. At the same time, however, they were "involve in segmenting religious thought into different disciplines and in narrowing the vision of many who passed through this process of defining religious believes" [1].

\section{Terrorism vs. Madaaris}

International focus on countering terrorism and extremism has created a new level of debate about the role of madaris. Thousands of research papers, news articles and essays are published across the world, which discusses the roles of madrassah education in the domain of promoting violence and terrorism. Authors [2] discuss that the Ulema (religious instructors) of various schools do not have a consistent approach about the syllabus and financing of madaris. These distinctions are profoundly established in the, in the light of the fact that teachers and students of madaris belongs to the various fragments of society". He additionally highlights that some madrassas have left their original duties of giving religious education to the students and are imparting their extremist views anticipating their own school of thought, which in returns increases the threat of terrorism.

Authors [3] recognizes that the educational curriculum of madaris is decrepit and these madaris promotes sectarianism by discrediting believes of people from other sects.

Authors [4] discuss the historical perspective of reforms applied for madaris. This research contains some significant data related to these educational reforms. Study presents the reforms applied on Indian madrassa that can be taken as a role model for the rest of world. The author [5] accepts that a segment of the Ulema additionally supports educational reforms with a specific goal of adjusting themselves according to the needs of modern world. He believes that the religious and social administrations of the madaris ought to be recognized by the government bodies and specific roles should be assigned to all of them in order to retain peace in the society.

\section{Curriculum of Madaris}

The best way to deal with military related controversy against Madaris is to make better choices about the educational curriculums. Madaris are not necessarily the dens for terrorists; instead there are many other main stream institutions which are hubs for terrorists [6]. Different educational perspectives of madaris education and their effects on the society are highlighted in a book written in the Urdu language. This book endeavors to satisfy the prerequisite of understanding the continuous procedure and patterns of changes in religious institutions on the premise of gatherings with the government and the immediate observations of fifty-six people leading religious education institutions across the Pakistan, belonging to different school of thoughts [7].

\section{Purpose of study}

The paradox lies in the fact that in a country where the literacy rate is as low as $40 \%$, madrassas contribute to enhance literacy rate in the most impoverished regions of Pakistan. Students from rural areas which are living below poverty line are interested in getting admission in madrassas as they do provide food, shelter, and clothing, but do not enable them to break the cycle of exclusion and poverty as they exclude them from mainstream education, and economic activities of country. Madrassa beneficiaries are economically, socially, and educationally alienated from the working domain of society. Madrassa education thus hinders economic development of the state by alienating youth from participating productively in the economic and social development spheres.

\section{Significance of the study}

Madrassah education is a symbol of religious unavoidable affiliation of Muslims. This study aims to focus on the role of the curriculum of the madaris education and need of changings in it. These reformations consist of a lot of prolific modifications which are substantial in coping with the modern world.

\section{Objectives of the study}

1. To what extent there is need of modern education in madaris.

2. Whether or not the curriculum of the madaris education system need amendments.

\section{Research questions}

1. Why is there need of modern education system in madaris?

2. What type of amendments recommended in the curriculum of madaris education in order to cope with the modern world?

\section{Limitation of the study}

As this research emphasises on the need for modern education in madaris of Lahore and modification in the existing curriculum. Hence, the researcher focused only on these two domains because of a shortage of time and resources. Other areas related to madaris education is still vacant for future studies.

\section{Literature Review}

In the previous section reveals that most of the authors have only focused on the very few issues related to the madaris. There is some work which annotates the educational system of madaris, but these studies do not confer prevalent challenges and problems faced by them. Different reforms are implemented on both national and international level to resolve these issues, but the problem is still unsolvable. An investigation based on essentialist hypothesis and assumptions, outdated apprehension, and fallacies have further obscured the subject. In Pakistan, the madaris are envisaged as a substantial source of wisdom where two million students are getting an education. It is the responsibility of the society and state to discern the structure of madrassa education and to put more efforts for its augmentations by considering the obligation of the hour. So in this perspective, this study is conducted to find out the space for the induction of science and modern education in the existing madaris [8]. 


\section{Educational system of Pakistan}

As a developed country, Pakistan has a very low literacy rate. According to the report of UNDP published in 2013, Pakistan is ranked at 146 in education among others [9]. In the context of Pakistan, another reason for the adoration of madrassah education is the absence of concrete infrastructure for the schools and educational institutions. Furthermore, the presence of government schools transcendently in the rustic territories of Pakistan has likewise depreciated the educational system of the country. So overall these educational institutes are not able to provide education to the people in these rural areas. There is a high drop-out ratio of children from schools in Pakistan. Some of them quit the formal education in fifth grade during school. While others leaves school at tenth grade and this process keeps on going at different educational levels. The financial reason is a major cause that contributes towards this. Students are more interested towards procuring a living for their family instead of gaining a formal education. In Pakistan, positive momentum of educational sector is hampered by a number of issues like immaterial budgetary allotments for the education sector, fewer enrolment rates, altogether high dropout rates, and intense local and gender discriminations [10]. Intensifying the circumstance are issues of dissimilarity in getting to and cooperation 'by social class (poor versus rich), are of living areas (urban versus rural) and gender orientation [11]. People involved in the politic are from an affluent and elite class which are not aware of basic needs of the lower class and their substantial problems. And also they believe that educational infrastructure will give awareness to the people so they should not be educated, in this way that they can never be well aware of their interests.

The statistics about the Pakistan education gives intimidating figures about the literacy ratio. Out of seventy million children, only forty percent are enrolled in school (ages between five and nineteen). Due to the worst infrastructure of government schools, madrassa education is the only pragmatic option for a large number of children from poor class as the private schools do not provide any support to this huge group of students. In addition, enormous learning crevices exist amongst government and private educational infrastructure, the private ones performs much better in academics [12]. But common man belonging to the lower class of society is not able to pay the fees of these schools due to financial crisis among the society [13].

\section{Madaris - A historical overview}

Madrassah is an Arabic word meaning school or Islamic educational institution. In Islamic history, madrassahs were the major source of religious and scientific learning, especially between the 7th and 11th centuries, producing luminaries such as Alberuni, Ibne-Sina, AIKhawarizmi and Jabir Ibne Hayan.

Schools in Damascus and Baghdad are comparable to greatest contemporary educational intuitions. During the Abbasid period (750-1258 AD), a need for designing an effective educational system is considered, in order to fulfill the administrative requirements of the muslim empire. Because of these reasons madaris are developed as a separate educational institution. The first madrassa was established in Morocco [14].

The curriculum taught in madaris incorporated the teaching of Hadith and Quran with expanding accentuation on fiqh. The knowledge of fiqh is considered compulsory in order to trained people for the justice courts. The subjects of science, medical and astronomy were also taught in these madaris. Afterwards, Muslim rulers established madaris in different areas. This educational system was brought to Indo-Pak by Turkish rulers. And the implementation of these madaris brings a huge socio-political change on the soil of indoPak [15].

\section{Relationship between Madaris and Islamisation}

In the context of Pakistan, it can be distinctly stated that the tale of its legislative issues since the independence is one of an explicit quest based on the self-interests of Pakistani ruling communities. These ruling elites have masked their own interests in the form of religion. The strategy of this class is to represent Pakistan as an ideological state based on Islamic religion but not a democratic state [16]. In Pakistan, different constituents of Islam have played a vital role in shaping the structural view of Madrassahs. Islamisation can be essentially characterized as a procedure in which "religion" became a shelter and encompassing supreme force for living. Islamisation consists of administrative practices along with the official and lawful activities through which people spend their lives. Islamisation has turned out to be pretty much synonymous with the governmental issues of administration survival in Pakistan [17].

The relationship between Islamisation and madrassah education is based on both complementary and supplementary grounds. Religion is the vital additive of Pakistani cultural identity and social legacy, the instructive framework of madrassa education conveys the obligation to extend and reinforce this legacy [18].

Islamisation can be viewed as one reason behind the expansion of the madrassah educational system in Pakistan. Also, in the meantime, madrassah as a free unit of education adds to the movement of Islamisation through its philosophy and supporters.

\section{Madaris educational system in Pakistan}

Pakistan has basically three types of different educational systems as mentioned:

1. Public School system

2. Government School system

3. Madrassa system

Madaris in Pakistan are divided into five categories depending on the types of sects. Each madrassah has its own board or Wafaq. Each board has its own educational system and different administrative policies. All of these madaris are a member of Ittehad Tanzeemat Madaaris Deenia (ITMD), which is an administrative organization for all madaris, established in 2003. The five types of madaris are following:

1. Tanzeem ul-Madaaris (Barelvi)

2. Wafaq ul-Madaaris al-Arabia (Deobandi)

3. Wafaq ul-Madaaris al-Shia (Shia)

4. Wafaq ul-Madaaris al-Salafia. (Ahl-e-Hadith)

5. Rabita ul-Madaaris al-Islamia (Jama'at-e-Islami).

Barelvi, Deobandi, Shia and Ahl-e-Hadith are considered to be the sects on whom these madaris are based on. While Jama'at-e-Islami do not belong to any particular sect.

Madrassas have their own curriculum which is one of the unique parts of Pakistani education systems. Madrassas in Pakistan serve to provide educational service to the most underprivileged rural 
communities. Because of their centuries old curriculum, their contribution to the socio-economic development of Pakistan is largely insignificant. They are teaching debilitated curriculum divided into two categories named as Uloom Aliya (sciences and Uloom Aliyya (Arts). The first category contains the Hadith, Fiqh and Quran. This first category is compulsory to study for students. The Second category which is based on Arts is quite flexible, but the method used to teach these subjects are burdensome and boring. The curriculum used for teaching Uloom Aliyya is based on the old philosophical logics which are imprecise and fuzzy. Due to which madrassa students lack modern knowledge and professional skills, which do not allow them to participate properly in various activities based on the economic development and policy. There is contemplative requirement to add subjects like Political Science, History, Economics and comparative religious studies in the curriculum of madrassa education. Religious scholars like Allama Shibli Numani has shared their concerns about the needs of modern curriculum integration with the old curriculum a century ago [19].

\section{Reasons for popularity of Madaris}

In all those areas where public educational infrastructure is either practically not implemented or is unable to fulfill educational needs of society, madrassas serve to provide an alternate source of education. Another major reason for the popularity of madrassas in Pakistan is that majority of families living below the poverty line cannot even afford the diminutive fees they charge. Madrassas also offer other propensities like free shelter, food, school books, clothing, and in some cases even a diminutive stipend. A large number of madrassas are located in the rural belt of northern Punjab. Most of them have plenty of funds at their disposal in terms of zakat and external funding from Saudi Arabia [20].

\section{Students in Madaris}

During the Sultanat and Mughal periods conventional madaris attract students from all social classes but now these madaris consider only the lower class students, the proletariat, and the poor with few exceptions. This change of criteria in selection of students has changed largely the standard of education in these madaris, and now this curriculum is no longer considered as the effective medium to provide the standardize and modern education. The education system of Muslim countries portrays inflexible dualism between customary madaris and modern school systems, it is important to notice that a large number of families send one of their child to madrassa and the rest of standard schools.

As compare to the madaris located in rural areas, the students in madaris in other cities of Pakistan also belongs to rural areas. Students that are studying in the madaris of Karachi belong to different parts of the country representing all the districts. Students from Pashton families are always outnumbering as compare to any other background [21]. The students that graduate have ages between 17 and 27 years. The girl students of madaris are younger as compare to the boys. Reason for age difference is that, their course duration is shorter than boys.

Madaris with more funds attracts more students belonging to different community background. Admission process of a conventional madaris is quite informal. Some of them have an entrance test while most of them are very flexible about the admission process. Larger madaris have specific dates for admission application; usually these are after the Islamic month of Ramzan [22]. The schedule of admission is advertised through wall posters and leaflets. In case of smaller madaris, the procedure of getting admission is very simple and student can get admission at any time within a year. Smaller madaris do not have enough budgets to advertise about their admission opening schedules. Most madaris have an open policy for admission with no adamant entrance requirements.

\section{Critical aspects of Madaris}

About $50 \%$ of these madrassas are located in the rural and urban areas of Punjab. The curriculum of madrassas is generally perceived as promoting sectarianism, intolerance, and violent attitudes amongst its students. Sectarian politics has increased domestic feud among various Islamic sects, with considerable security implications for the country. Another important criticism against madrassah education is that it has little or no bearing about the modern needs of the society. Therefore, it is extremely important to explore the system and consequences of this type of education [22].

According to the National Education Policy Pakistan, madrassa education system is a different system running in parallel to the public and private educational systems. It is further recognized by the education policy that different education systems with different curriculum causes many controversies in society. Exclusively, based on the sectarian and political grounds, there are four other different types of madrassah oriented educational aspects with conflicting doctrines.

Most important question that arises is how the educational system of these madrassas can help the students to deal with the challenges of modern world by using their religious education. Is there any method to add modern education in the curriculum of these institutions and if yes then how many institutions are willing to do that? Madrassa system of education is not able to overcome the gap between the modern needs of world and the curriculum taught (Table 1).

\begin{tabular}{|l|l|l|}
\hline Provinces & Registered Madrassas & Unregistered Madrassas \\
\hline Punjab & 7,303 & 6,479 \\
\hline Khyber Pakhtunkhwa & Not mentioned & 4,135 \\
\hline Balochistan & Not mentioned & 266 \\
\hline Sindh & 6503 & 3087 \\
\hline
\end{tabular}

Table 1: Madrassa system of education in different provinces in Pakistan. 
However it has been observed that madrassah system of education has not been incorporated with modern educational prospects. Also madrassa organizers oppose the modernization of curriculum because of communication gaps and misunderstanding. On the other hand madrassa system of education is against terrorism and extremism but because of lack of modern technology they are not able to communicate their apprehensions to the rest of world.

\section{Reforms of government of Pakistan}

After 9/11 many aspects of madrassa education has come in to lime light due to which Pakistan has remained under high pressures from the Western world. Different ignored dimensions of Madrassa educational system predicts that few of them are deviated from their substantial responsibilities and are involved in terrorist and anti-state activities. To overcome these issues, government has intended to bring flexible reforms in the educational systems of madrassas. Large numbers of reforms are required in order to register all these madrassahs with the government. There are still number of madrassahs which are not formally registered with government of Pakistan. National Action Plan (NAP) has been placed for the purpose of Madrassa registration. Almost forty to fifty percent of these madrassas are not registered according to the statistics presented in different reports. Because of this reason it's easy for these institutions to get involved in the terrorist activities.

Government of Pakistan has initiated several mechanisms to integrate madrassas with the mainstream formal education system, since both systems are running in parallel to each other with minimal or no similarity. Religious madrassas are autonomous institutions their curricula are developed independently "in consultation with their scholars and ulemas".

The government of Pakistan selected a working group for developing measures to facilitate integration of the two systems. In August 2001, Pakistan Madrasa Education Board (PMEB) has been created by government for establishing and regulating the madrassas, under the Pakistan Madrasa Education Board Ordinane, 2001. The mandate of PMEB was to build up model madrasas and to manage and affirm conditions of existing theological colleges on the suggestions of its Academic Council. The PMEB affiliates the already existing madrassas in the private sector. This affiliation was provided as a motivation so that madrassah also focus on the modern curriculum. The significant work of PMEB's huge is the foundation of three model madrassas, two in Sindh (Karachi and Sukkhur) and one in the Islamabad.

The reforms produced by the reform board contends that disparate curriculums are being used by various madrassahs in the country; "the variety of curricula leads to variety of output and sectarian groupings.

The faculty of each madrassa institution has different qualification and expertise. Some of them are equipped with highly qualified staff with special teaching expertise while the others do not meet these standards. The curriculum variation coupled with faculty differences may cause quality degradation. The working group on madrassas proposed the certain reforms to align educational system of madrassas with the needs of the modern society. These reforms also highlight that administration of most madrassas is not willing to support the reform efforts. Any policy action taken from government is considered as threat to their independence. Following are the madrassa reforms proposed by the working committee.
- Teaching of English, Economics, Mathematics and Pakistan Studies at Secondary level in 150 outstanding madrassahs.

- Teaching of English, Economics, and Computer Sciences at Intermediate level in 200 outstanding madrassahs.

- Training one thousand teachers in formal education through Workshops.

- Equipping libraries of 70 madrassas with modern books.

- Teaching English, Math's, General Science and Social Studies in 3000 madrassahs at secondary level for integration of their system with formal education system.

- Teaching English, Economics, Pakistan Studies and Computer Science at Higher Secondary level in 2000 madrassahs.

- To provide 10 computers and 2 printers each to 200 madrassahs for teaching Computer Science at higher secondary level in 2000 madrassahs and equip their computer lab.

- To equip libraries of 5000 madrassahs through reference books, furniture, etc.

- To impart training to 2000 teachers of 5000 madrassahs to update their knowledge and teaching experience in the formal subjects through two week duration workshops in different parts of the country.

- To provide a vehicle to each institution for providing facilities of pick and drop lo their institutions.

These reforms also suggest that the integration of both systems would be a major step for improvements in the quality of education - a leading factor responsible for socio-economic uplift of the society. Madrassas that are already established would become a base for accelerating the old educational system.

\section{Methodological Overview of Collected Data}

Methodology adopted for proposed research domain is based on a case study of the madrassa education system in the Lahore Division of Pakistan. Conducting an interview base study provides a better understand about the operational mechanism of madrassah system. The objective of the in-depth analysis is to connect the madrassah system to socio-economic and political factors by assessing its effect on the lives of the people who are the part of this education system. This study employs the qualitative research methods in order to explain the nature of relationship between madrassa education and modern needs.

\section{Population of the study}

Participants were all males (the study was conducted in the urban areas of District Lahore where only male students are enrolled in madrassahs; co-education does not exist in these madrassas; the teachers and administrators are also males). The age of the participants ranged from 18 to 68 years. Group of participants are both student and teachers. In terms of class, the participants ranged from working class (low income group) to middle class from an array of different sects/ schools of thoughts. The participants in this study are associated with four madrassahs located in the urban areas of District.

Lahore and included madrassahs administrators/teachers, and graduates (who had completed the course of studies at their respective madrassas; equivalent to high school). 
Page 6 of 8

\section{Data collection tool}

Method including interviews and these interviews contain open ended questions. Total of 107 participants take part in the interview session which is conducted on one to one basis.

Questions explored their perceptions, understandings, and values about the domains like the goals and purposes of madrassa education, type of curriculum used in the madrassas, socio-economic background of the students, reasons for which parents send their children to madrassas, economic opportunities available to madrassa graduates, and the career options they take up after graduation. Additionally meetings with these madrassahs 'administrators, teachers, and students are also conducted.

\section{Sample size}

Sampling method employed for the data is stratified sampling as the certain group of people with particular demographics are selected. Sample size of 107 students is taken from the different Madrassas in Lahore.

\section{Demographic description}

Demographic overview of Sample participants is as follows (Table 2).

\begin{tabular}{|l|l|l|}
\hline Variables & Frequency & Percentage \\
\hline Family Size & & \\
\hline 01-Mar & 9 & 8.5 \\
\hline 04-May & 39 & 36.4 \\
\hline 6 & 52 & 48.6 \\
\hline Did not Response & 7 & 6.5 \\
\hline Fathers Occupation & & \\
\hline Personal Business & 39 & 36.4 \\
\hline Employed & 50 & 46.7 \\
\hline Unemployed & 13 & 12.1 \\
\hline Did not Response & 5 & 4.7 \\
\hline Sect & & \\
\hline Barailvi & 34 & 31.8 \\
\hline Dyoband & 33 & 30.8 \\
\hline
\end{tabular}

Table 2: Demographic overview of Sample participants.

\section{Data Analysis}

Data is analyzed in three steps. At the first step, descriptive statistics is computed for items of the scales. At the second step, a series of Chisquare goodness of fit test were carried out to assess the different responses of the participants for each item of scientific education in Madrassa.

In final step chi square test of independence is conducted to assess the association between variables. All these analyses were conducted through SPSS (version 20). Data analysis details are not presented in order to keep the article short.

\section{Discussion}

During interviews, Madrassa students share their experiences and highlights that they have multiple problems like poor infrastructure, unemployment, lack of basic necessities like electricity water and gas. Also due to the fund raising activities, they are considered as terrorists and their egos are hurt.

After the analysis of data collected from the interviews, it is revealed that they are not satisfied with their education system and also this system is less adaptable for them as compare to other private and public educational systems. Also they feel that they do not have any kind of job opportunity in different fields of science and arts, after completing their education.

It is also concluded from findings that madrassa students prefer that the scientific knowledge of Science, Mathematics and Economics is equally important in order to face the challenges of new millennium. Also internet is an important source of education in madrassa system of education whereas madrassa teachers are not very comfortable with the latest system of education.

Madrassa students also agreed upon that education of jihad is also important along with the Hadees and Fiqh education, where as they do not agree with the concept of co-education education system in madrassas.

They also claimed that Islamic education does not promote terrorism and it is also found that Islam is not the reason of war in the world. They strongly believe that Islam is a religion of peace and if someone is considering Muslims as terrorists then this is seriously a false obligation. Not all as few of Madrassas are using for terrorist activities which is in interest of some other people. Results of chi 
Page 7 of 8

square test of independence showed that the students who opted madrassah with choice and who did not, are not much satisfied with the madrassah education. Moreover the students who lived with good living conditions and who did not said that madrassa should be run under the government supervision. On other hand, students who prefer co-education system were of the opinion that it is more likely to promote vulgarity. Furthermore the students who prefer scientific education in madrassah were more likely in favor of internet usage.

\section{Conclusion}

In this section the main conclusions derived from this study is discussed, relative to the empirical evidence and findings from the document analysis in relation to religious education system in Pakistan and its role in the development of the state.

Public Education Sector in Pakistan suffers from insufficient financial input, low levels of efficiency for implementation of practical reforms along with the poor quality of management, monitoring, supervision, and teaching strategies. As a result, Pakistan has one of the lowest rates of literacy in the world, and the lowest among countries of comparative resources and social/economic situations. The literacy rate in Pakistan is low (approximately 44\%) and average per capita income is around $\$ 900$ [13].

The analysis of the empirical evidence related to the four madrassas, located in Lahore, suggests that all of these madrassas provide free education and basic facilities, such as boarding, food, and clothing to students from the most under privileged areas of the rural areas. Madrassahs (religious schools) thus provide an essential service to the economically impoverished families that cannot afford to educate their children through public or private education systems mainly because of poverty.

Parents send their children prefer this type of education due to two main reasons: poverty and to receive Islamic education and training. Madrassah graduates mostly tend to join other madrassas and mosques as priests and teachers, where they teach Islamic studies to children from the local communities. Some also teach Islamic studies and Arabic at public schools. They teach children about fundamental principles of Islam and how to read the Quran; also helping them to memorize the Quranic text.

\section{Suggestions}

The conclusion of the study supports the following factors:

- Majority of the graduates from these madrassas are not able to participate in the economic activities of country due to their decrepit studies. However, some of them take join the professions of teaching in public schools, business, and agriculture.

- The government is making efforts to integrate madrassa education with formal public education system in order to enable madrassas to play a more visible and active role in national and economic development.

- The Government of Pakistan hopes that the integration of two systems would be a major step for improvements in the quality of education - a major factor responsible for socio-economic uplift of the society.

- Both religious and formal education in madrassas should be implemented practically. Also vocational training should also be included in madrassahs curriculum.
- Madrassah education is generally not preparing its students to participate in mainstream economic activities. Madrassah education in Pakistan further alienates people from the most disadvantageous sections of the society by creating a welfare system, which does not prepare its students to join the mainstream developmental sections of the society. The government is making efforts to reform this religious education system so that it can play a more effective role in national development. Madrassa teachers, graduates, and administrators, who participated in this study, are also in favor of including formal education in madrassahs curriculum.

- Government should provide training and high salaries to madrassah teachers. "Higher salaries" from the government would help them to meet family needs and expenses.

- However Madrassah administration has strong reservation regarding the policy and procedure the government wants to adopt in registration of these madrassah to bring them in main stream.

- Different recommendations that can be considered valuable in the context of the domain are as follows:

- Government in power should take serious steps for considering the Madrassah education as an important part of education system. So that people do not consider Madrassah education only a source of Islamic education but do consider them as the source of inspiration for real world advancements.

- Every Madrassa should be legally registered with the government and process of registration should be easy and flawless, so that all the activities running inside the madrassas should be kept under serious observations.

- Islamic and educational curriculum taught in madrassah system should be modernized and according to the latest trends so that students of madrassahs can later on effectively deal with the real world challenges.

- Government must defend all these Islamic institutions on serious grounds in front of all other countries, so that western world should know that these places are not for the terrorists, but these are peaceful institutions like other universities and colleges.

- There should be some monitory committees which visit the madrassas on monthly or yearly basis so that activities of these institutions should be kept in line with the main stream activities of the other government institutions.

- Proper funding system should be implemented for their financial needs so that standards of these institutions can be according to the modern world.

\section{References}

1. Ahmed S, Stroehlein A (2005) Pakistan: Still Schooling Extremists. Washington Post.

2. Ahmad Z (2000) Islam and Muslims in South Asia, Delhi: Authors Press.

3. Maleeha A (2003) The Process and Impact of Ideologization of Islam in Pakistan.

4. Krishna K (2007) Education and Culture: India’s Quest for a Secular Policy. In Kumar, Krishna and Oesterheld, Jaochim (eds.) Education and Social Change in South Asia, New Delhi: Orient Longman.

5. UNDP Human Development Report (2013).

6. Amneh S (2006) Warring ideologies: The use of education policy to control religious fundamentalism in Pakistan. (Unpublished Master's Thesis) Crowford School: The Australian University.

7. Zia R (2003) Religion and education in Pakistan: an overview. 33: 165-178. 
Citation: Anjum U (2017) Assessing the Need of Modern Education in Madrassah System: A Case Study of Madaris in Lahore. Arts Social Sci J

Page 8 of 8

8. Das J, Pandey P and Zajonc T (2006) Learning Levels and Gaps in Pakistan. World Bank Policy Research Working Paper 4067.

9. Asadullah N (2009) Returns to private and public education in Bangladesh and Pakistan: A comparative analysis. J Asian Economics 20: 77-86.

10. INDO-ASIAN NEWS SERVICE (2003) Pakistan: Huge Increase In Madrassas.

11. Ashraf M (2012) Transnational Terrorism, Madrassa Education and Present National Education Policy of Pakistan, The Need for Educational Research to Champion Freedom, Education and Development for All ECER.

12. Rathore M (2015) Comprehensive review of NAP Registration of madrassas and NAP.

13. Haider I (2015) IGP report reveals 147 foreign-funded seminaries in Punjab. Dawn Nes, Paksitan.

14. Gishkori Z (2015) Uniform standards: Most unregistered Madaris in K-P says officials. Express Tribune.
15. Ahmad M (2004) Madrassa Education in Pakistan and Bangladesh.

16. Ghitreef $M$ (2015) Changes in Madrasa Curriculum Is a Must.

17. Zaidi SMA (2013) Madrassa Education in Pakistan: Controversies, Challenges and Prospects. Centre for International and Strategic Analysis.

18. Noor FA, Sikand Y, Bruinessen M (eds.) The Madrasa in Asia Political Activism and Transnational Linkages. Amsterdam Press.

19. Ahmed ZA (2009) Madrassa education in the Pakistani context: Challenges, reforms and future directions. South Asian J Peace Build.

20. Rahman K, Bukhari SR (2005) Religious Education Institutions (REIs): Present Situation and the Future Strategy. Institute of Policy Studies, 2.

21. Shahzad A, Malik RK, Sarwat K, Ayesha K, Ayazz R (2014) The Issues of Madrasa Students in Pakistan: A Qualitative Investigation. Arts Social Sci J 5: 76.

22. Hussain K (2005) Reforming the Madrassah system of instruction. Daily Dawn Karachi. 